\title{
The Analisys of the Roles Teacher for Implementing Learning of 4.0 Industrial Revolution (A Case on Elementary School of Jakarta)
}

\author{
Nurrohmatul Amaliyah ${ }^{1}$ \\ ${ }^{1}$ Primary Educataion Program of UHAMKA Graduate School \\ nurramaliyah@uhamka.ac.id
}

\begin{abstract}
The background of this research is based on a phenomenon from the primary school teacher candidates. These teachers will face a study process in the classroom with various student character in this millennium era nowadays. The teacher candidate must have an essential skill to face the learning ambiance where the student criticism is gradually increase annually. Application of school curriculum must in-line with student requirement nowadays. The problem is, how the role of the teacher in application of 4.0 era learning model in the primary school of Jakarta. Aim of this research is to analyze the role of the teacher in application of 4.0 era learning model in primary school in Jakarta area. Research method in this study is descriptive analysis method. The application of descriptive method will describe education activity phenomena and learning process of the primary school teachers in the classroom. Category of this research is case study research category in form of a data collection and analysis to the learning process. Data collections are observation activity, questioner, and interview. Research instruments to acquire the information for this research are audio recording and field note. As the result, the teacher has no capability yet to be a mediator and inspiration for the application of technology in 4.0 era learning model in the primary school of Jakarta. This caused by the learning implementation still practice a conventional method with teacher centered learning model and the evaluation activity is not based on interactive media. Moreover, the teacher has no capability to perform the interactive applications significantly and lack of innovation during learning process. Additionally, an availability of infrastructure and supporting facility must be upgraded. For example, not all the students have a gadget and the student have no sufficient interest to study. For that reason, a study on student centered learning model should performs for the primary school in Jakarta.
\end{abstract}

Keywords: role of the teacher, learning model, era of industry 4.0.

\section{INTRODUCTION}

Education is one of the most important things in human life. Education is a human consciousness effort to create a comprehensive personalty. The education is also considered as the most capable tool to create a better human resources quality for the future. Therefore, in any part of this world, the education participates and becomes an important variable to determine the way and goal of a country. Including Indonesia. As a developing country, Indonesia puts the education as the main consideration, especially in the context of the creation of human resources quality. Education in Indonesia continuously developed time to time to achieve the educational objective as stated in the Preamble of the 1945 Constitution. Various policy practiced and developed by the government to realize the educational objective of Indonesia, develop nation's intellectual. Therefore, the problem formulations of this research are: 
1. What implementations have already done during learning classroom activity by the primary school teachers of Jakarta?

2. How far the evaluation during the learning classroom activity by the primary school teachers of Jakarta?

3. What factors that influence the learning activity from the teacher in their class?

\section{METHOD}

Research Approach. The method in this research is descriptive analysis method, a method to describe or explain the object of the research based on the data and samples collected as it is without analysis and compile a general conclusion (Sugiono, 2009: 29). In other words, descriptive analysis research identifies the problem or focus to the problems during the research activity. Then, the result of the research processed and analyzed to compile the conclusion. Consequently, the author in analysis of role of the teacher during the application of 4.0 learning model in primary school of Jakarta, Indonesia, use descriptive analysis method because the method suitable to identify the current and existing phenomena.

Research Subject. The subject of this research is a primary data source as informant to describe the role of the teacher in implementation of 4.0 learning model. The subject of this research is primary school teachers in area of Jakarta, who has acquired a training for the latest curriculum, 2013 curriculum. These teachers are divided based on the area, West Jakarta, East Jakarta, South Jakarta, North Jakarta, and Central Jakarta.

Research Object. The object of this research is how the role of the teacher in application of 4.0 learning model. According to (Sugiyono: 2011) social situation is consist of three components, place, actor, and activity. The place is the place where social situation happens, actor (agent/man) is an actor who played specific role, and activity is perform by the actor in actual social situation.

\section{Research Flow Chart}

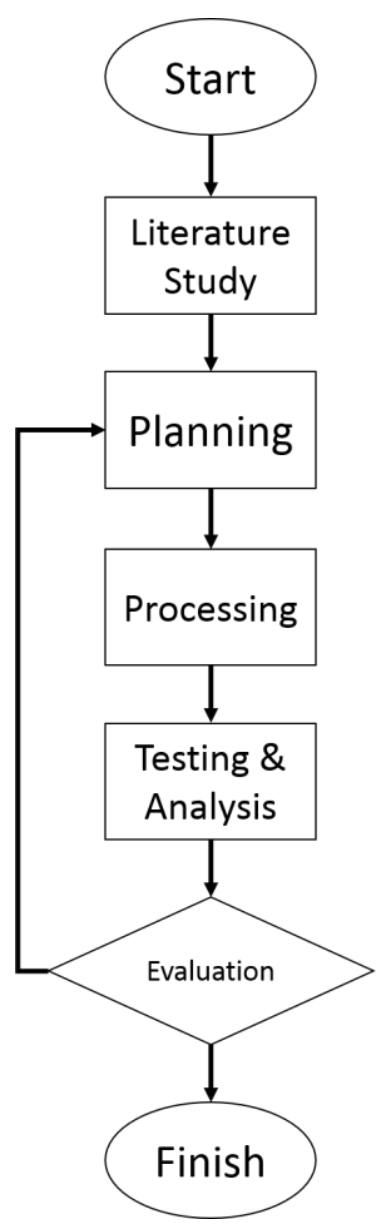

\section{RESULTS AND DISCUSSION}

\subsection{The Result}

\subsubsection{Implementation of learning activity in classroom by the primary school teachers of Special Capital Region of Jakarta}

According to interview, most of teachers during the application of study still practices a conventional method, such as lecture format, as supported by the statement of Class Supervisor of IV SD Cakung Barat 7, "The teacher has no courage to leave their comfort zone, from lecture learning method." The conventional method will impact to the result of learning outcome and complementation of student learning outcome. The teacher fells a great comfort to not change their learning model. In fact, all facilities have provided in era of education 4.0 to support the teacher during their classroom activity, such as 
Google Classroom, others applications facilities with cooperative learning methods that suits for the teacher.

Learning in Education 4.0 era requires a variation of teaching method to prevent the burned out of the student. Therefore, the teacher should adapt their learning method in accordance with the presented material. In addition of the method, the teacher must have capability to present an interesting media to attract student exciting, enthusiasm, and interest to the literature that create a learning process becomes better.

This result supported by observation and interview in primary school of SDN Pekayon 05 Pagi. There are some teachers still applied a conventional learning method, such as lecture learning model. According to the interview result, there are some students still not understand to the teacher presentation who applied the lecture method. This conventional instruction model provides the teacher becomes active during the learning process and the student must hear the teacher presentation. The learning model indirectly only centers to the teacher and the student becomes a passive participant. The student is not active during the learning process because of poor participation of the student. The teacher with lecture model is only focus to the material without consider the active participation of their student during the learning process.

The student needs various learning process as the result of SD Cakung Barat primary school research. During the learning process of this school, the teacher still applied an old paradigm, the teacher presenting a knowledge to the student passively. As a result, the student only sit, silent, hear, taking a note, and memorize. The learning process impression is boring and the student has no enthusiasm during their study. The teacher should practice a centered learning model to the student that create an active and creative student. One of the efforts to increase the outcome is a selection of learning model, a model that the student is the center of the learning process.

Learning activities during COVID-19 pandemic is not a face to face learning process but utilize the WhatsApp Group mobile phone application that creates a barrier for the student to learn their material directly as is in classroom activity. Learning process through WhatsApp Group should creates a possibility to the teacher to make an innovation. In fact, as a result of the field observation, most of the teachers only presents a homework without presenting a interesting learning media. Moreover, the teacher has a possibility to use an online learning media to present the material or assignment to the student [1]. Moreover, the teacher may also utilize the modern technology through online learning or called as elearning. This system is a learning model that exploit the information technology and communication [2]. There are some applications or sites to support e-learning model in Indonesia. Examples of the website or application are
Ruang Guru, Edmodo, Zenius.net, and etc. Facility provides by the 4.0 Industrial Revolution era in education sector is more flexible and efficient as a presence of video that explain about the subject material, exercise, and online try out, supported by a quality teacher who always available when necessary. All internet-based learning process makes a learning process can perform anywhere and anytime.

\subsubsection{Evaluation of learning activity in classroom by the primary school teachers of Special Capital Region of Jakarta}

A successful of student from the learning activity may identify from the process and the learning achievement including the indicator of achievement, an absorption of the material, and achievement target of the learning process. In order to know the goal achievement, evaluation becomes a systematic process to measure student successful for the learning target achievement.

Learning evaluation is a process to achieve a result and information about the learning outcome of the student. According to the result of this research, many teachers not utilize the technology yet. As stated by the Class Supervisor of IV grade of Cakung Barat Primary School, where "Learning evaluation activity is only in form of exercise activity based on the answer sheet." Consequently, SDN Cakung Barat 07 not yet practice learning model variation and no implementation in technology utilization during their learning evaluation. According to this fact, the learning evaluation is still practicing a conventional method and rarely utilize the technology application. In fact, the learning evaluation possibly practice by various method and various media, such as gamification learning method, inquiry, and problem-solving method that would create an interactive learning evaluation and the student will have a critical thinking to the presentation of the material during the learning process.

The interview result explains about an obstacle of the teacher when performing the evaluation, the creation of evaluation instrument. Most of the teachers reuse the previous exercise that presented frequently previously and does not consider the differences of student capability each year. In fact, the evaluation process must perform in accordance with the student capability level. Consequently, the teacher will be able to analyze an obstacle during the learning process from their student.

Evaluation must be conducted distinctively and not only emphasis to one aspect only. According to [3], [4]there are two aspects for the evaluation process, test evaluation and non-test evaluation. Evaluation with test emphasis to measure the intelligent capabilities and for non-test evaluation will describe the characteristic, attitude, and student personality. As supported by [5]the 
evaluation instrument must fulfill some conditions which are valid, reliable, objective, equal, distinctive, norm, fair, and practical.

According filed interview result, some teachers experiences obstacle when practice the evaluation based on interactive media because the limitation of time, cost, and lack of facility and infrastructure support, such as book and others learning resources. An associated cost brings an influence when utilize media with numerous tools and materials. The cost will increase to buy some tools and materials or at least the usage of internet subscription quota will expensive. Consequently, the primary school teacher in Jakarta prefer to cut down the cost by using photocopy paper only and even the teacher prefers to write down on the white board.

\subsubsection{Supporting and obstructive factors in the classroom learning activity of the Jakarta primary school teacher}

Learning process in Education 4.0 era demands the teacher to innovate continuously. On the contrarily, the implementation is different, many teachers consistently practice the conventional method. According to the analysis and interview result, there are various factors that influences the learning activity of Jakarata primary school teachers:

a. supporting factors

1) School facilities is sufficient, such as computer room and internet access.

2) Information that required by the teacher to support the learning process mostly acquired from internet and accessible.

3) Environment, such as school principal support, significantly influence to the successful of learning process.

b. obstacle factors

1) Internal factors, for example a limitation of teacher capability, no innovation from the teacher when presenting the lesson inside the classroom, and monotonic learning method. In addition, inaccuracy and inappropriate of planning, implementation and learning evaluation produces a poor result. Most of the teachers, especially the senior teacher, not realizes if there are numerous applications that will supports and creates the learning process becomes a fun process. In fact, the teacher capability is the determinant that control the classroom.

2) A completeness of structure and infrastructure influences a successful of a learning activity. According to observation and interview result, structure and infrastructure supporting facility must be upgraded, for example LCD monitor in every classroom and visual aid tools.

3) Student enthusiasm to the learning process is poor as described during the observation. Lack of interest to learn from student is caused by monotonous from the teacher when selecting the learning method and lack of attention from the parent to their child during the learning process.

During COVID-19 pandemic, the learning process is a remote study that required a gadget. However, most of the students use their parent's gadget. Consequently, one of the biggest obstacles is the time. If the gadget is belonging to their parent and the gadget is not available when their parent goes to work for a communication tool, then some students can not follow the material than the others students. Moreover, an availability of internet data package and internet network access for each parent is different each other. Therefore, during the assignment process or presenting the material, the student supposed to be minimum in the usage of internet quota that produce the teacher poor in innovation.

\subsection{Discussion}

Today, the world faces the 4.0 Industrial Revolution, indicated by an increasing in connectivity of the people, machine, and data, that changes countless sector of this life. One of the sectors is education sector. The education challenged to create a capability to utilize the technology, especially the internet for the learning process. However, during the implementation, most of the teachers still practice the conventional learning model. The conventional learning model is known as a daily learning process and a habit that continuously practice everyday. One of the characteristic features of this learning model is the learning activity. All the learning activity is teacher centered. The teacher is the presenter who provide the material while the student is only become a passive audience. In accordance with Sanjaya cited in (Ibrahim, 2017), consider the conventional model generally practices the lecture method to deliver the material. The role of teacher dominates this learning model and minimize the student participation during the learning process. Moreover, the exploration of the knowledge that need by the student becomes restricted and time to wait the presentation of the teacher becomes increase. As a result, learning activity in conventional model is only focus on lecture activity and the communication characteristic is only oneway communication.

According to the research of [6]), education experience a great disruption. Role of the teacher as the only one of scientific knowledge presenter is gradually changing away. Future role and teacher presences in 
classroom will have significant challenge and requires a great creativity.

In reality, kids during the age of Primary School prefers to interactive and colorful educational games. For that reason, the teacher may utilize the application of gadget to attract the student personally during the learning process. The teacher must have ability to realize the Education 4.0 as stated by Qusthalani (2016) that explain five competencies to prepare the teacher to enters the 4.0 Industrial Revolution, which are:

a. educational competence, a learning competency based on internet as a basic skill,

b. competence for technological commercialization, a teacher must have competency to present their student with entrepreneurship attitude based on the technology from the result of the student work in innovation,

c. competence in globalization, the teacher familiar with the various culture and have capability to solve the education problem,

d. competence in future strategies, competency to predict the future accurately and its strategy through joint lecture method, joint research, joint resource, staff mobility, and rotation,

e. counselor competence, a teacher competency to understand that the future problem of the student is not only hard to understand the learning material but also about psychological that cause by the current development.

When the teacher have those skills, then the teacher will have capability to present a fun learning to create a student skill for their age period as stated by Frydenberg \& Andone (2011), where in order to against the learning process in 21 century, every people must have critical thinking ability, knowledge, and digital literation, literation of information, media literation, and advance in information technology and communication. Additionally, the result of Punchreobuth research (2016) stated that "Therefore, it is not enough to define the education for 21st Century Skills only, but also to consider the learning management in the aspect of Social \& Virtual Learning; that the graduates will become intellectuals and eventually that would help to build an intelligent nation." Consequently, the teacher has a challenge, not only creating a skill for their student but also creating a capability for their student to build an intelligent nation.

In order to achieve the aim and learning goals, some learning principles should considered as explain by Gerstain (2014), where the characteristic of learning principle which towards to the Education 4.0 are:

a. The student determines and develop their own a learning material. In addition, the student create their own learning objective for the learning purposes based on various desired learning outcome. b. The student selects their learning preference and technology to determine how the process of their learning activity.

c. Creating their own learning community because of various social network application existence nowadays, by using a recommended social network tool and or prepared by their educator. Some possible social networks todays are: Facebook®, Twitter, Edmodo, Instagram, blog site, YouTube $®$, and other social networks.

d. The student taking an advantage from the expertise of their educator and others members from their learning community to introduce the resource that related to the content and others online network for their learning demonstration and creating a learning artifact.

In order to implementing the learning in era of Educataion 4.0, Nurkholis (2019) stated that the teacher must improve their competency to teach their student based on internet of thing, competent to guide the student with entrepreneurship attitude based on technology, problem solving skill, competent to predict the future accurately and its strategies, and becomes the counselor/psychologist. The role of the teacher during the learning (Sofan Amri, 2013) are:

a. As a corrector who evaluate and review all learning outcome, attitude, behavior, and student action.

b. As an inspirer who inspiring their student about how to study properly.

c. As an informant who providing a good and effective information about the planned material and information about the development of scientific knowledge and technology.

d. As an organizer who organize various academic activity, either intra-curricular or extra-curricular.

e. As a motivator who motivate their student consistently and high spirit and study actively.

f. As an initiator who initiate the further ideas in education and learning.

g. As facilitator who provided a facility for optimum learning process of their student.

h. As a guidance who provided to their student to against the challenge or learning obstacle.

i. As a demonstrator who demonstrate the current material didactically, this the student will understand the material optimally.

j. A good classroom organizer because the classroom is the gathering place of the educator and learner.

k. As a mediator who provided a media and mediator for the student during the learning process.

1. As a supervisor who helped, improved, and evaluated critically the learning process activity to become an optimal process.

m. As an evaluator who has capability to evaluate the learning product and learning process. 
The role of the teacher as the educator is building a basic value for character development of the learner life, including the advantage of information technology advancement wisely and as inspiration for their learner (Effendy, 2019). Even a fast-growing development in information technology and an accessibility of learning resources is easy but the role of teacher as the educator can not replace by the technological progress and it will happen if the teacher is study and develop their competency continuously.

Evaluation process should perform during the learning process based on the student condition, in accordance with Law No. 20/2003 Article 53 Section 1, where the learning outcome evaluation of the learner performs to help the process, progress, and development of learning outcome of the learner continuously. In the era of Education 4.0, everything is digital, evaluation needs a media as stated by Titiana et.al. (2019) where the interactive learning media based on technology is in-line with the Pavlov learning theory, the learning process participating the stimulus process of teacher and student response. The teacher presenting the information accurately and fun, then the learning process of the student inside the classroom will respond in accordance with the stimulus of the teacher during the learning process (a serious teacher presents material with interactive media support, then the student will fully concentrate and complete the evaluation from their teacher). As a result, an effective, efficient, and fun learning process happen with interactive media as supported by the technology.

The teacher must rule the learning innovation to prepare their mental and ability to perform the learning with various approach and learning model to achieve a successful in learning process. Moreover, a sufficient facility and infrastructure is required, for example media, tool, and learning resource to achieve the learning objective. Most of obstacle factors is comes from the educator. The educator is not only demanding to have ability to plan their study activity, preparing the teaching material, planning the media and learning resources but also must be able to implement their planned program.

A professional teacher is the determinant factor for a quality educational process. The teacher in era of information technology and communication today is not only about to teach (transfer of knowledge) but also must become a learner manager. It means, every teacher should have ability to create a condition of learning that stimulate the student creativity and activity, motivating their student, utilize multimedia, multi method, and multi source to achieve an expected learning goal. A professional teacher must expertise in science and technology comprehensively and not partially because the science and technology development are fast. Teacher without strong knowledge in science and partial understanding will left behind and not competent to follow the development of scientific knowledge and technology. This teacher will be left behind far away and exclude from their profession.

As a result, the teacher should increase their qualification on expertise and academically, changes their wisdom and perception from old classical pattern, improve their previous attitude and behavior that will visible for their learner, and welcome to the development and fast-growing technological progress.

\section{CONCLUSIONS}

Implementation of classroom learning activity by primary school teacher of Jakarta is not significant. Most of the teacher consistently practice a conventional method, the teacher presenting a knowledge to their student passively and the student is only sitting, silence, hear, taking a note, and memorize. An application technology, such as WhatsApp Group, is only to deliver the homework and presenting a simple material.

Evaluation for classroom learning activity by the primary school teacher of Jakarta is not significant because some teachers has difficulties to use an evaluation based on interactive media and the teacher is not frequently participate the technology advantage. As a result, the critical thinking of the student is not significant to the presented material during the learning process.

There are some factors that influence the learning activity as presented from the teacher inside the classroom. The supporting factor is information accessibility as a source of learning resources. The obstacle factor that influence the learning process from the teacher to the student is internal factor, including lack of ability to use interactive applications and lack of innovation when presenting the material. Moreover, availability of facility and infrastructure that should be upgraded are gadget and student interest is minimal during the learning process because not all the students have a gadget.

\section{REFERENCES}

[1] C. Anggraeni, "Promoting Education 4.0 in English for Survival Class: What are the Challenges?," Metathesis J. Engl. Lang. Lit. Teach., vol. 2, p. 12, Apr. 2018, doi: 10.31002/metathesis.v2i1.676.

[2] "Keefetifan e-learning sebagai media pembelajaran (studi evaluasi model pembelajaran e-learning SMK Telkom Sandhy Putra Purwokerto) | Hanum | Jurnal Pendidikan Vokasi." https://journal.uny.ac.id/index.php/jpv/article/view/ 1584 (accessed Jan. 22, 2021).

[3] D. Kustawan, Pendidikan Inklusif \& Upaya Implementasi. Luxima Metro Media, 2012. 
[4] D. Kustawan, Pendidikan inklusif\&upaya implementasinya. Luxima, 2012.

[5] H. M. Sukardi, "Evaluasi Pendidikan Prinsip dan Operasionalnya," Jkt. Bumi Aksara, 2008.
[6] "Pendidikan Islam di Era Revolusi Industri 4.0 | SALIHA: Jurnal Pendidikan \& Agama Islam," Accessed: Jan. 22, 2021. [Online]. Available: https://staitbiasjogja.ac.id/jurnal/index.php/saliha/ar ticle/view/33 